\title{
Risk Severity Framework for a BOT Highway Project
}

\author{
By K.Srinivas, Assistant Professor, \\ National Institute of Construction Management and Research (NICMAR)
}

\begin{abstract}
Adequate attention needs to be given to project risk management for reaping the benefits by way of meeting the objectives of an organisation. Organisations which implement good risk management practices derive maximum advantage by way of fewer risks which are quite manageable in general and more so in infrastructure sector which is subjected to plethora of risks. The role of infrastructure in the overall development of a nation cannot be underscored. Considering this, a study has been carried out for an ongoing highway project being executed in the state of Telangana (India) under NHAI. The study was carried out by administering the questionnaire to 250 experts associated with highway sector and the response received was 110. The respondents were asked to identify the risks in four phases of a project namely Feasibility phase, Development Phase, Execution Phase and Operation phase and also the likelihood and impact of each of the identified risks. The severity of risk was determined based on the likelihood and impact of risks and was categorized accordingly. The severity of risk indicates the extent to which the project is exposed to that particular risk and the mitigation measures need to be taken accordingly to minimise the effect of risk.
\end{abstract}

Keywords: Risk assessment, Risk severity

\section{Introduction}

Construction industry right from the conceptual phase to commissioning of project is subjected to risks which needs to be addressed by the stakeholders concerned. In recent times, the nature, incident and impact of risk in construction industry has become a topic of interest because of its effects on quality, time and cost of construction projects (Ojo, 2010, Windap et al 2010 and Joshua 2010) Risk is important to contractors, clients and consultants within the construction industry. Construction activities are subjected to plethora of risks which have to be considered by the management if they are to achieve their objectives.As per Project Management Institute (PMI, 1996) "Risk is uncertainty and result of the uncertainty or lack of predictability about structure, outcome or consequences in a planning or decision situation". Risk management is defined as "entire set of activities and measures that are aimed at dealing with risks in order to maintain control over the project"

Construction risk management is the process of identifying, analyzing and mitigating the risks in the project by proper response (PMI,2003).According to www.antive.net(2012),project risk management involves risk identification, risk analysis, creating a risk response action plan, monitoring and controlling of risks in a project. ISO 31000 defines "Risk Management as identification, assessment, and prioritisation of risks followed by coordinated and economical application of resources to minimise, monitor, and control the probability and/or impact of unfortunate events or to maximize the realization of opportunities. Risk Management's objective is to assure uncertainty does not deflect the endeavor from the business goals. Martin Schieg (2006) defines "Risk management constitutes a strategy to avoid losses and use available chances potentially arising from risks. The strategy demands from the person to take a precise "consideration" and "assessment" of the situation and the scenarios likely to occur in future. This means recognising potential risks and circumventing a threat by averting , evading or reducing their negative effects"An infrastructure project by its very nature is subjected to variety of risks and hence the impact of risks on the project if it were to occur will be substantial. This study is confined to a highway project in state of Telangana (India) by considering various risks in the four phases of the project and calculating the severity of each risk based on which suitable risk mitigation measures have been proposed.

\section{Literature Survey}

Al-Bahar and Crandall ${ }^{1}$ on systematic risk management approach for construction projects have concluded that brainstorming sessions and analysis of historical data of similar projects were found to be the most preferred methods of risk identification in construction industry and that formal risk management process is used infrequently. Ahmed et $\mathrm{al}^{2}$ in his study has concluded that complexities of projects, locations and type of contracts are significant contributors to risk in construction projects. Ijigah Edoka Augustine et $\mathrm{al}^{3}$ on risk management practices in Nigerian construction industry have concluded that risks are not properly managed and that there is need for strategy to reduce the risks by way of formulation of effective risk management index.YYL Florence et $\mathrm{al}^{4}$ have concluded that every infrastructure project is subjected to multiple risks and it is the responsibility of promoter to promoter to mitigate the risks by having a strong management team and a 
comprehensive risk management should be conducted and mitigation plan be prepared for ensuing the success of project. Baloi et $\mathrm{al}^{5}$ did a modeling study on global risk factors affecting the cost performance in construction projects and have concluded that there is need to incorporate global risk factors in any project for effective project mitigation. Debasis Sarkar et al ${ }^{6}$ on Project Risk Management Framework for PPP models for Indian highway projects have developed a framework for project risk management for PPP models for Indian Highway projects. Jonathan k.Fabi et $\mathrm{al}^{7}$ have conducted a study on risk Management practice of highway projects in Nigeria and recommended that adequate training for all stakeholders in highway construction sector for effective management of risks and for meeting the project objectives. Kansal RK et $\mathrm{al}^{8}$ in their study on risk assessment methods and application in construction have concluded that various methods of risk assessment like brainstorming, checklist, Delphi method and risk significant index methods are used and each method has its own limitation and that risk assessment methods can be integrated for applying risk management effectively. Shehu et $\mathrm{al}^{9}$ have stressed that construction is a risk prone industry with poor track record of coping with risks as a result of which clients are not able to reap full benefits of their investment. Nerija Banaitiene et $\mathrm{al}^{10}$ have concluded that risk management is the core of project management and that success of any project depends on how effectively uncertainties are handled. DadaJ $\mathrm{O}$ et $\mathrm{al}^{11}$ on evaluation of impact of risk in construction industry have identified political risk as the main risk factor and that contingency amount in the estimate should be based on procurement method. Debasis Sarkar et $\mathrm{al}^{12}$ in their study on project risk management in underground construction of metro rail have concluded that cost uncertainties and risks should essentially be carried out for infrastructure projects and that risks involved in infrastructure project from concept to commissioning, if not treated properly, probability of successful completion of project gets diminished.Shen LY and et $\mathrm{al}^{13}$ in their study on risk assessment for construction joint ventures in china have observed that risk transfer is an effective tool for mitigating the risks in infrastructure projects. Martina Claudia Garrido et $\mathrm{al}^{14}$ in their study have concluded that formal risk identification and application techniques in Brazilian construction industry is rarely used and that more informal methods are applied for risk identification. Rinaj Pathan et $\mathrm{al}^{15}$ in their study on Risk assessment of BOT projects have evaluated the role of financial stability of the project and its subsequent effect on risks and concluded that a BOT project gets affected by various parameters like toll structure, toll revision schedule, extent of government grant etc and that project sponsor and promoter need to arrive at an agreement on sharing of risks for effective risk mitigation.

\section{Research Methodology}

Data for the study was collated through a questionnaire that was administered to 250 participants of the project which is being executed in the state of Telangana (India). The recipients of Questionnaire were clients/ developers, architects, contractors, consultants, engineers etc who were involved in construction of project.. The response received was $110(44 \%)$. The respondents were asked to furnish the likelihood of occurrence of a risk(L) and its impact(I) on a scale of 1 to 5 whose connotation is given below

Table:1 : Connotation for Likelihood and Impact of risk

\begin{tabular}{|l|l|l|}
\hline Scale & $\begin{array}{l}\text { Connotation for } \\
\text { likelihood }\end{array}$ & $\begin{array}{l}\text { Connotation } \\
\text { for Impact }\end{array}$ \\
\hline 1 & Improbable & Insignificant \\
\hline 2 & Unlikely & Marginal \\
\hline 3 & As likely as not & Serious \\
\hline 4 & Probable & Critical \\
\hline 5 & Highly probable & Catastrophe \\
\hline
\end{tabular}

Based on the responses furnished by the respondents, the weighted average likelihood and impact is calculated as follows:

Weighted average $=\sum($ Number of responses $*$ Concerned Numerical scale $) /$ response received

After calculating the weighted average likelihood and impact, the severity of risk was calculated as $\mathrm{L}+\mathrm{I}-($ L*I) where L \& I are brought on a scale of 0 to 1 by dividing with 5. The connotation for severity of risk is given as follows

Table 2: Connotation for Severity of Risk

\begin{tabular}{|l|l|}
\hline Range of Values & Severity of Risk \\
\hline $0.0-0.2$ & Nil \\
\hline $0.21-0.4$ & Insignificant \\
\hline $0.41-0.6$ & Significant \\
\hline $0.61-0.8$ & High \\
\hline $0.81-1.00$ & Very high \\
\hline
\end{tabular}




\section{Risk Assessment}

Table 3: Risk Assessment (Feasibility phase)

\begin{tabular}{|c|c|c|c|c|c|c|c|c|c|c|c|c|}
\hline \multirow[t]{2}{*}{ Risk } & \multicolumn{5}{|c|}{$\begin{array}{l}\text { Responses } \\
\text { ( Likelihood) }\end{array}$} & \multicolumn{5}{|c|}{$\begin{array}{l}\text { Responses } \\
\text { ( Impact) }\end{array}$} & \multirow{2}{*}{$\begin{array}{l}\text { Weighted } \\
\text { average } \\
\text { Likelihood of } \\
\text { risk }\end{array}$} & \multirow{2}{*}{$\begin{array}{l}\text { Weighted } \\
\text { average } \\
\text { impact of risk }\end{array}$} \\
\hline & 1 & 2 & 3 & 4 & 5 & 1 & 2 & 3 & 4 & 5 & & \\
\hline $\begin{array}{l}\text { Reliability of } \\
\text { Feasibility Report }\end{array}$ & 42 & 34 & 17 & 13 & 6 & 34 & 28 & 29 & 13 & 6 & 2.21 & 2.35 \\
\hline $\begin{array}{l}\text { Approval and } \\
\text { permit risks }\end{array}$ & 11 & 33 & 41 & 14 & 11 & 8 & 14 & 36 & 30 & 22 & 2.83 & 3.4 \\
\hline Political risks & 30 & 41 & 17 & 14 & 8 & 18 & 25 & 47 & 14 & 6 & 2.35 & 2.68 \\
\hline Legal risks & 38 & 41 & 19 & 8 & 4 & 22 & 28 & 30 & 14 & 16 & 2.08 & 2.76 \\
\hline $\begin{array}{l}\text { Environment and } \\
\text { social risks }\end{array}$ & 24 & 28 & 35 & 12 & 11 & 21 & 30 & 34 & 19 & 6 & 2.61 & 2.63 \\
\hline
\end{tabular}

Table 4: Risk Assessment (Development phase)

\begin{tabular}{|c|c|c|c|c|c|c|c|c|c|c|c|c|}
\hline \multirow[t]{2}{*}{ Risk } & \multicolumn{5}{|c|}{$\begin{array}{l}\text { Responses } \\
\text { ( Likelihood) }\end{array}$} & \multicolumn{5}{|c|}{$\begin{array}{l}\text { Responses } \\
\text { ( Impact) }\end{array}$} & \multirow[t]{2}{*}{$\begin{array}{l}\text { Weighted average } \\
\text { Likelihood of risk }\end{array}$} & \multirow{2}{*}{$\begin{array}{l}\text { Weighted } \\
\text { average } \\
\text { impact of risk }\end{array}$} \\
\hline & 1 & 2 & 3 & 4 & 5 & 1 & 2 & 3 & 4 & 5 & & \\
\hline $\begin{array}{l}\text { Resettlement \& } \\
\text { Rehabilitation }\end{array}$ & 19 & 27 & 48 & 11 & 5 & 23 & 30 & 43 & 11 & 3 & 2.06 & 2.46 \\
\hline Design & 24 & 33 & 27 & 16 & 10 & 19 & 24 & 35 & 22 & 10 & 2.59 & 2.81 \\
\hline $\begin{array}{l}\text { Environment and } \\
\text { social risks }\end{array}$ & 22 & 30 & 33 & 13 & 12 & 20 & 22 & 38 & 18 & 12 & 2.66 & 2.81 \\
\hline Market & 18 & 26 & 37 & 16 & 13 & 23 & 30 & 33 & 17 & 7 & 2.81 & 2.59 \\
\hline Legal & 19 & 38 & 41 & 7 & 5 & 23 & 27 & 30 & 14 & 16 & 2.46 & 2.75 \\
\hline Political & 29 & 53 & 13 & 9 & 6 & 22 & 27 & 49 & 8 & 4 & 2.18 & 2.5 \\
\hline Financial closure & 27 & 33 & 21 & 18 & 11 & 29 & 36 & 25 & 14 & 6 & 2.57 & 2.38 \\
\hline
\end{tabular}

Table 5: Risk Assessment (Execution phase)

\begin{tabular}{|c|c|c|c|c|c|c|c|c|c|c|c|c|}
\hline \multirow[t]{2}{*}{ Risk } & \multicolumn{5}{|c|}{$\begin{array}{l}\text { Responses } \\
\text { ( Likelihood) }\end{array}$} & \multicolumn{5}{|c|}{$\begin{array}{l}\text { Responses } \\
\text { ( Impact) }\end{array}$} & \multirow{2}{*}{$\begin{array}{l}\text { Weighted } \\
\text { average } \\
\text { Likelihood } \\
\text { of risk }\end{array}$} & \multirow{2}{*}{$\begin{array}{l}\text { Weighted } \\
\text { average } \\
\text { impact of } \\
\text { risk }\end{array}$} \\
\hline & 1 & 2 & 3 & 4 & 5 & 1 & 2 & 3 & 4 & 5 & & \\
\hline Utility diversion & 20 & 28 & 16 & 19 & 27 & 16 & 33 & 31 & 23 & 7 & 3.05 & 2.74 \\
\hline Force Majeure & 22 & 30 & 35 & 15 & 8 & 7 & 11 & 22 & 39 & 31 & 2.61 & 3.69 \\
\hline Traffic diversion & 3 & 18 & 20 & 52 & 17 & 10 & 13 & 25 & 40 & 22 & 3.56 & 3.46 \\
\hline Safety & 20 & 27 & 43 & 13 & 7 & 11 & 25 & 38 & 23 & 13 & 2.64 & 3.01 \\
\hline Time over run & 9 & 22 & 49 & 21 & 9 & 8 & 10 & 36 & 33 & 23 & 2.99 & 3.48 \\
\hline Cost Overrun & 11 & 24 & 39 & 26 & 10 & 8 & 16 & 42 & 25 & 19 & 3 & 3.28 \\
\hline Construction & 24 & 33 & 27 & 16 & 10 & 16 & 34 & 31 & 23 & 6 & 2.59 & 2.71 \\
\hline Inflation & 25 & 34 & 23 & 16 & 12 & 17 & 25 & 31 & 24 & 13 & 2.6 & 2.91 \\
\hline Contractual & 29 & 30 & 25 & 15 & 11 & 18 & 20 & 22 & 40 & 10 & 2.54 & 3.03 \\
\hline
\end{tabular}

Table 6: Risk Assessment (Operation phase)

\begin{tabular}{|c|c|c|c|c|c|c|c|c|c|c|c|c|}
\hline \multirow[t]{2}{*}{ Risk } & \multicolumn{5}{|c|}{$\begin{array}{l}\text { Responses } \\
\text { ( Likelihood) }\end{array}$} & \multicolumn{5}{|c|}{$\begin{array}{l}\text { Responses } \\
\text { ( Impact) }\end{array}$} & \multirow[t]{2}{*}{$\begin{array}{l}\text { Weighted average } \\
\text { Likelihood of risk }\end{array}$} & \multirow{2}{*}{$\begin{array}{l}\text { Weighted } \\
\text { average } \\
\text { impact of risk }\end{array}$} \\
\hline & 1 & 2 & 3 & 4 & 5 & 1 & 2 & 3 & 4 & 5 & & \\
\hline Traffic Revenue & 19 & 26 & 37 & 16 & 12 & 23 & 30 & 33 & 18 & 6 & 2.78 & 2.58 \\
\hline Market & 16 & 25 & 30 & 29 & 10 & 21 & 29 & 34 & 24 & 2 & 2.92 & 2.61 \\
\hline Safety & 28 & 30 & 33 & 14 & 5 & 20 & 32 & 37 & 18 & 3 & 2.44 & 2.56 \\
\hline Force Majeure & 29 & 33 & 21 & 17 & 10 & 17 & 22 & 31 & 26 & 14 & 2.51 & 2.98 \\
\hline $\begin{array}{l}\text { Social and } \\
\text { Environmental }\end{array}$ & 13 & 42 & 35 & 18 & 2 & 11 & 43 & 35 & 17 & 4 & 2.58 & 2.64 \\
\hline Legal & 19 & 39 & 41 & 8 & 3 & 23 & 29 & 30 & 13 & 15 & 2.42 & 2.71 \\
\hline $\begin{array}{l}\text { Transportation } \\
\text { of hazardous } \\
\text { chemicals }\end{array}$ & 9 & 24 & 29 & 32 & 16 & 7 & 15 & 22 & 40 & 29 & 3.2 & 3.71 \\
\hline
\end{tabular}




\section{Risk Severity}

Table 7 : Risk Severity(All Phases)

\begin{tabular}{|l|l|l|l|l|}
\hline Risk & Likelihood & Impact & $\begin{array}{l}\text { Risk value } \\
\text { L+I }-(\text { L*I })\end{array}$ & Risk Severity \\
\hline Feasibility Phase & & & & \\
\hline Reliability of Feasibility Report & 2.21 & 2.35 & 0.704 & High \\
\hline Approval and permit risks & 2.83 & 3.4 & 0.861 & Very High \\
\hline Political risks & 2.35 & 2.68 & 0.754 & High \\
\hline Legal risks & 2.08 & 2.76 & 0.738 & High \\
\hline Environment and social risks & 2.61 & 2.63 & 0.773 & High \\
\hline Development Phase & & & & \\
\hline Land Acquisition & 2.65 & 2.78 & 0.791 & High \\
\hline Resettlement \& Rehabilitation & 2.06 & 2.46 & 0.701 & High \\
\hline Design & 2.59 & 2.81 & 0.789 & High \\
\hline Bidding & 2.57 & 2.2 & 0.728 & High \\
\hline Environment and social risks & 2.66 & 2.81 & 0.795 & Very High \\
\hline Market & 2.81 & 2.59 & 0.789 & High \\
\hline Legal & 2.46 & 2.75 & 0.771 & High \\
\hline Political & 2.18 & 2.5 & 0.718 & High \\
\hline Financial closure & 2.57 & 2.38 & 0.745 & High \\
\hline Technology Selection & 2.37 & 2.26 & 0.711 & High \\
\hline Execution Phase & & & & \\
\hline Utility diversion & 3.05 & 2.74 & 0.823 & Very High \\
\hline Force Majeure & 2.61 & 3.69 & 0.874 & Very High \\
\hline Traffic diversion & 3.56 & 3.46 & 0.911 & Very High \\
\hline Safety & 2.64 & 3.01 & 0.812 & Very High \\
\hline Time over run & 2.99 & 3.48 & 0.878 & Very High \\
\hline Cost Overrun & 3 & 3.28 & 0.862 & Very High \\
\hline Construction & 2.59 & 2.71 & 0.779 & High \\
\hline Inflation & 2.6 & 2.91 & 0.799 & Very High \\
\hline Contractual & 2.54 & 3.03 & 0.806 & Very High \\
\hline Operation Phase & & & & \\
\hline Traffic Revenue & 2.78 & 2.58 & 0.785 & High \\
\hline Market & 2.92 & 2.61 & 0.801 & Very High \\
\hline Safety & 2.44 & 2.56 & 0.750 & High \\
\hline Force Majeure & 2.51 & 2.98 & 0.799 & Very High \\
\hline Social and Environmental & 2.58 & 2.64 & 0.771 & High \\
\hline Legal & 2.42 & 2.71 & 0.764 & High \\
\hline $\begin{array}{l}\text { Transportation } \\
\text { chemicals }\end{array}$ & 3.2 & 3.71 & 0.907 & Very High \\
\hline & & & & \\
\hline & & & & \\
\hline & & & & \\
\hline & & & & \\
\hline
\end{tabular}

\section{Conclusions}

1. All the risks are in the category of high and very high and hence as such risks in the project are quite substantial

2. Almost all the risks in the execution phase are in very high category which means that these risks have the potential to derail the project

3. In the development phase, environment and social risks is in very high category which meant that risk of displacement of people as well as the effect on the environment is substantial

4. In the feasibility phase, risk of approval and permit is in very high category and hence sufficient attention should be paid to mitigate this risk.

5. Adequate attention should be given to Market, Force Majeure and Transportation risks in Operation phase.

6. Suitable risk mitigation measures by way of risk transfer, risk sharing and risk reduction is to be put in place so as to minimise the effect of risk in the event of its occurrence.

7. On the whole it can be inferred that risks in infrastructure projects are of potentially damaging nature and unless suitable risk management is in place, the chances of a successful project outcome is remote.

\section{References}

[1]. Al-Bahar J and Crandall K(1990), Systematic Risk Management Approach for Construction Projects, Journal of Construction Engineering and Management116(3),pp533-546

[2]. Ahmed, et al(1990),Decision support system for modeling bid/no-bid decision problems, Journal of Construction Engineering and Management, ASCE,116(4), pp595-608

[3]. Ijigah Edoka Augustine, Jimoh Richard Ajayi, et al, (2013), Assessment of Risk Management Practices in Nigerian Construction Industry-Toward establishing Risk Management Index, International Journal of Pure and Applied Sciences and Technology,16(2), pp20-31 
[4]. Florence YYL and Linda H (2006), Risk faced by Singapore Firms When undertaking Construction projects in India, International Journal of Project Management,24(38),pp261-270

[5]. Baloi D and price ADF (2003),Modelling Global Risk factors Affecting Construction Cost Performance, International Journal of Project Management,21,pp261-269

[6]. Debasis Sarkar and Kintan Patel ( 2012), Project Risk management Framework for PPP models for Indian Highway Projects, Ciivl engineering and Construction review Journal, 25(03), pp 104-112

[7]. Jonathan.k.Fabi and Jacob A.B.Awolesi ( 2015), A study of Risk Management practice of Highway projects in Nigeria, Journal of Economics and Sustainable Development, 6(18), pp 171-177

[8]. Kansal RK and Manoj Sharma (2012),Risk Assessment methods and Applications in Construction Projects, 2(3), pp1081-1085

[9]. Shehu Z and Sommerville J (2006), Real Time Risk Management Approach in Construction Projects, Glasgow University, Glasgow, United Kingdom

[10]. Nerija Banaitiene and Audrius Banaitis, Risk Management-Current Issues and Challenges,_ISBN 978-953-51-0747-7, InTech, September 9, 2012

[11]. Dada J O and Jagboro G O (2007),Evaluation of Impact of Risk on Project Cost Overrun in Nigerian Construction Industry, Journal of Financial Management of property and Construction, 12(1), pp37-44

[12]. Debasis Sarkar and Goutam Datta(2011),A framework of Project Risk Management for the Underground Corridor Construction of Metro Rail, Indian Institute of Management, W.P No:2011-02-05

[13]. Shen LY and Ng, CSK(2001),Risk Assessment for Construction Joint Venture in China, Journal of Construction Engineering and Management,127(1),pp76-81

[14]. Martina Claudia Garrido, Morano Cassia,Riberio and Assed (2011),Risk Identification Techniques Knowledge and Application in Brazilian Construction,2(11), pp242-252

[15]. Rinaj Pathan and Dr Pilplikar S S( 2013), Risk Assessment of BOT Road Projects, IOSR journal of mechanical and Civil Engineering, 5(3), pp 40-59 